\title{
Optimation and Validation of Analytical Method of Cotrimoxazole in Tablet and Plasma In vitro by High Performance Liquid Chromatography
}

Harmita*, Umar Mansur and Jenni Sartika

Department of Pharmacy, Faculty of Mathematic and Science, University of Indonesia, West Java, Indonesia

\begin{abstract}
A simple and reproducible high-performance liquid chromatographic method was developed for simultaneous determination of sulfamethoxazole (SMX) and trimethoprim (TMP), which are also known as cotrimoxazole, in tablet and human plasma in vitro. The Concentration of TMP and SMX used for this study were 1:5 according to their combination as cotrimoxazole. Chromatography was performed on a $\mathrm{C}_{18}$ column $(250 \mathrm{~mm} \times 4.6 \mathrm{~mm}, 5 \mu \mathrm{m}) \mathrm{under}$ isocratic elution with acetonitrile-water-triethylamine (20:80:0.1 v/v), pH $5.9 \pm 0.1$ arranged by $0.2 \mathrm{~N} \mathrm{NaOH}$ or $1 \%$ acetic acid. Detection was made at $240 \mathrm{~nm}$ and analyses were run at a flow-rate of $1.0 \mathrm{ml} / \mathrm{min}$ at a room temperature. Sulfadimidine was used as internal standard. In tablet validation, the calibration curve was linear by $r$ values 0.9994 and 0.9996 , precision by coefficient of variation (CV) were $0.85 \%$ and $0.98 \%$ also accurate by $\%$ recovery for 3 concentrations were $98 \%-102 \%$ for TMP and SMX, respectively. Plasma extraction was done by deproteination with acetonitrile, mix with vortex for 40s, then centrifuge it on $12500 \mathrm{rpm}$ for 15 minutes. In plasma validation, the recovery was $94.95 \%$ and $86.87 \%$ for TMP and SMX, respectively. The lower limit of quantification (LLOQ) in plasma was $150 \mathrm{ng} / \mathrm{mL}$ and $750 \mathrm{ng} / \mathrm{mL}$ for TMP and SMX, respectively. The method also fulfill the criteria for accuracy and precision intra and inter day by $\%$ diff values not exceed $\pm 20 \%$ for LLOQ and $\pm 15 \%$ for concentrations except LLOQ. On the stability study, cotrimoxazole in plasma is pronounced to be stable for 30 days.
\end{abstract}

Keywords: HPLC; Sulfamethoxazole; Trimethoprim; Validation

\section{Introduction}

Cotrimoxazole, a combined drug consisting of 1 part of trimethoprim and 5 part of sulfamethoxazole, was introduced into clinical practice about 30 years ago and is still widely prescribed for various indications [14]. A combination of trimethoprim-sulfamethoxazole is effective treatment for a wide variety of infections including $P$ jiroveci pneumonia, shigellosis, systemic salmonella infections, urinary tract infections, prostatitis, and some nontuberculous mycobacterial infections. Trimethoprim in combination with a sulfonamide blocks sequential steps in folate synthesis, resulting in marked enhancement (synergism) of the activity of both drugs [11]. The combination often is bactericidal, compared with the bacteriostatic activity of a sulfonamide alone [14].

Because drug concentrations are an important element in determining individual or population pharmacokinetics, drug concentrations are measured in biologic samples, such as milk, saliva, plasma, and urine. Sensitive, accurate, and precise analytical methods are available for the direct measurement of drugs in biologic matrices. Such measurements are generally validated so that accurate information is generated for pharmacokinetic and clinical monitoring. In general, chromatographic methods are most frequently employed for drug concentration measurement, because chromatography separates the drug from other related materials that may cause assay interference [22].

Numerous HPLC methods for the quantification of cotrimoxazole in biological samples have been reported. These methods involved the use of protein precipitation, liquid-liquid extraction and solidphase extraction coupled with ultraviolet detection or ion pair chromatography or high performance liquid chromatography tandem mass spectrometry method (HPLC/MS/MS) [15,16,19].

In bioequivalence studies, the proposed method should be simple and able to process hundreds of samples in a limited time. This paper describes a simple, rapid, precise, and accurate HPLC method for determining cotrimoxazole in tablet and human plasma in vitro.

\section{Materials and Methods}

\section{Chemicals and reagents}

Trimethoprim (100,1\% on assay) and sulfamethoxazole (99,9\% on assay) were obtained from F. Hoffman-La Roche. Sulfadimidine was obtained from Nanhai Beisha Pharmaceutical. Acetonitrile and methanol were HPLC-grade and were purchased from Merck. The other chemicals and reagents were analytical grade. Human plasma was provided by Indonesian blood bank (Palang Merah Indonesia).

\section{Chromatographic conditions}

The HPLC system (Shimadzu, Japan) used consisted of a model LC-6A pump, a fixed manual injection loop of $20 \mu \mathrm{L}$, and a model SPD-6A UV detector; data acquisition was performed with the CBM102 processor. The analytical column employed was a Kromasil C18 column $(250 \mathrm{~mm} \times 4.6 \mathrm{~mm}$, i.d., $5 \mu \mathrm{m})$.

The mobile phase consisted of acetonitrile-water $(20: 80 \mathrm{v} / \mathrm{v})$ with the addition of triethylamine $(0.1 \% \mathrm{v} / \mathrm{v})$. The mobile phases were adjusted to $\mathrm{pH} 5.9 \pm 0.1$ with $0.2 \mathrm{~N} \mathrm{NaOH}$ or dilute acetic acid $(1 \%$ $\mathrm{v} / \mathrm{v})$, filtered through a $0.45 \mu \mathrm{m}$ cellulose membrane filter (Whatman)

*Corresponding author: Harmita, Department of Pharmacy, Faculty of Mathematic and Science, University of Indonesia, West Java, Indonesia, E-mail: harmita21@yahoo.co.uk

Received December 05, 2011; Accepted March 24, 2012; Published March 29, 2012

Citation: Harmita, Mansur U, Sartika J (2012) Optimation and Validation of Analytical Method of Cotrimoxazole in Tablet and Plasma In vitro by High Performance Liquid Chromatography. J Bioanal Biomed 4: 026-029. doi:10.4172/1948-593X.1000059

Copyright: (c) 2012 Harmita, et al. This is an open-access article distributed under the terms of the Creative Commons Attribution License, which permits unrestricted use, distribution, and reproduction in any medium, provided the original author and source are credited. 
and degassed before use (Elmasonic $\mathrm{S} 60 \mathrm{H})$. The detection wavelength was set at $240 \mathrm{~nm}$. Chromatography separation was performed at room temperature and flow rate was maintained at $1 \mathrm{~mL} / \mathrm{min}$.

\section{Standard solutions and quality control samples}

As stated above, cotromoxazole is fixed combination of 1 part of trimethoprim and 5 parts of sulfametoxazole. Therefore, this study used that ratio on making the solutions. Primary stock solutions of cotrimoxazole consisted of trimethoprim $(0.32 \mathrm{mg} / \mathrm{mL})$ and sulfamethoxazole $(1.60 \mathrm{mg} / \mathrm{mL})$ were prepared in methanol [25]. Cotrimoxazole stock solution was further diluted with mobile phase to obtain different concentration. Sulfadimidine as the internal standard were made by the same steps as above to achieve a $10 \mu \mathrm{g} / \mathrm{mL}$ solution.

Human plasma calibration standards of cotrimoxazole were prepared by spiking an appropriate amount of the working standard solutions into drug-free human plasma. The concentration of trimethoprim (TMP) and sulfamethoxazole (SMX) in calibration curve was $150 \mathrm{ng} / \mathrm{mL}, 420 \mathrm{ng} / \mathrm{mL}, 670 \mathrm{ng} / \mathrm{mL}, 830 \mathrm{ng} / \mathrm{mL}, 1000 \mathrm{ng} / \mathrm{mL}, 1170$ $\mathrm{ng} / \mathrm{mL}, 1330 \mathrm{ng} / \mathrm{mL}$ for TMP and $750 \mathrm{ng} / \mathrm{mL}, 2080 \mathrm{ng} / \mathrm{mL}, 3330 \mathrm{ng} /$ $\mathrm{mL}, 4170 \mathrm{ng} / \mathrm{mL}, 5 \mu \mathrm{g} / \mathrm{mL}, 5833 \mathrm{ng} / \mathrm{mL}, 6670 \mathrm{ng} / \mathrm{mL}$ for SMX. Quality control (QC) samples were prepared at three concentrations that were low (416.7 ng/mL for TMP and $2083.3 \mathrm{ng} / \mathrm{mL}$ for SMX), medium (666.7 $\mathrm{ng} / \mathrm{mL}$ for TMP and $3333.3 \mathrm{ng} / \mathrm{mL}$ for SMX), and high (1000 $\mathrm{ng} / \mathrm{mL}$ for TMP and $5000 \mathrm{ng} / \mathrm{mL}$ for SMX) concentrations.

\section{Sample preparation}

Cotrimoxazole tablet: The sample (cotrimoxazole tablet) was prepared by weighing 20 tablets and determining the average weight of the tablets. Then, we grind them and put some to weight accurately. We diluted the samples in methanol and sonication the for 30 minutes. For the final step, we used milipore membrane to filter it.

In human plasma: To a $1.5-\mathrm{mL}$ microtube were added $0.5 \mathrm{~mL}$ plasma, $25.0 \mu \mathrm{L}$ of the cotrimoxazole standard solution, and 25.0 $\mu \mathrm{L}$ of the internal standard working solution $(40 \mu \mathrm{g} / \mathrm{mL})$. One part of acetonitril $(190 \mu \mathrm{L})$ was added to precipitate protein in plasma, vortex-mixed for $20 \mathrm{sec}$, then add 4 part of mobile phase component into the tube so that the final volume was exactly $1.5 \mathrm{~mL}$. The result was repeatedly vortex for $20 \mathrm{sec}$ and centrifuged at $12,500 \mathrm{rpm}$ for 15 minutes. A $20-\mu \mathrm{L}$ aliquot of the supernatant was injected into the HPLC system.

\section{Validation of this method}

This method was successfully validated to measure cotrimoxazole in tablet $[4,5]$. The calibration curve was linear by $\mathrm{r}$ values 0.9994 and 0.9996 , precision by coefficient of variation $(\mathrm{CV})$ were $0.85 \%$ and $0.98 \%$ also accurate by $\%$ recovery for 3 concentrations were $98 \%$ - 102\% for TMP and SMX, respectively. With the same method, the validation process was being conducted to measure cotrimoxazole in blank plasma.

Six randomly selected blank plasma samples [6] were processed by a similar extraction procedure and analyzed to determine the extent to which endogenous plasma components may contribute to interference at the retention time of trimethoprim, sulfamethoxazole and sulfadimidine.

The calibration curves were constructed each day before the analysis of the samples by plotting the peak-area ratio (trimethoprim and sulfamethoxazole /sulfadimidine) versus the drug concentrations. The lower limit of quantification (LLOQ) was defined as the lowest concentration with a coefficient of variation (CV) of less than $20 \%$ and accuracy of $80-120 \%$. The accuracy and precision of the method were assessed intra-day and inter-day during 5 days by determining QC plasma samples at three concentrations which were low (416.7 ng/ $\mathrm{mL}$ for TMP and $2083.3 \mathrm{ng} / \mathrm{mL}$ for SMX), medium $(666.7 \mathrm{ng} / \mathrm{mL}$ for TMP and $3333.3 \mathrm{ng} / \mathrm{mL}$ for SMX), and high (1000 ng/mL for TMP and $5000 \mathrm{ng} / \mathrm{mL}$ for SMX) concentrations, accompanying by a standard calibration curve on each analytical run.

The recovery of cotrimoxazole was evaluated by comparing measured concentration obtained from peak areas of pre-treated quality control plasma samples $(n=5)$ with mean measured concentration of those spiked-afterextraction samples at the same nominal concentrations. The recovery of I.S. from plasma was evaluated at a concentration of $670 \mathrm{ng} / \mathrm{mL}$ using the same process. Stability quality control plasma samples were conducted at low and high concentrations and were subjected to short-term (6 h and $24 \mathrm{~h})$ incubation at room temperature, three freeze/thaw cycles, and storage for 30 days $\left(-20^{\otimes} \mathrm{C}\right)$. The stability of primary stock solutions were also being conducted for 40 days $\left(5^{\circledR} \mathrm{C}\right)$.

\section{Results}

\section{Specificity}

The current method showed excellent chromatographic specificity with no endogenous plasma interference at the retention times of trimethoprim, sulfamethoxazole and sulfadimidine as internal standard. Chromatograms obtained from human blank plasma and human blank plasma spiked with cotrimoxazole $(150 \mathrm{ng} / \mathrm{mL}$ of trimethoprim and $750 \mathrm{ng} / \mathrm{mL}$ of sulfamethoxazole) and sulfadimidine $(670 \mathrm{ng} / \mathrm{mL})$ are shown in Figure 1A, 1B, Trimethoprim, sulfamethoxazole and sulfadimidine respectively were well resolved with respective retention times of $6.3 \mathrm{~min}, 14.2 \mathrm{~min}$ and $8.5 \mathrm{~min}$.

\section{Calibration curve and limit of quantification}

The calibration curves were linear over the concentration range of $150-1300 \mathrm{ng} / \mathrm{mL}$ with a correlation coefficient of 0.9979 for trimethoprim and $750-6670 \mathrm{ng} / \mathrm{mL}$ with a correlation coefficient of 0.9976 for sulfamethoxazole. The correlation coefficient from
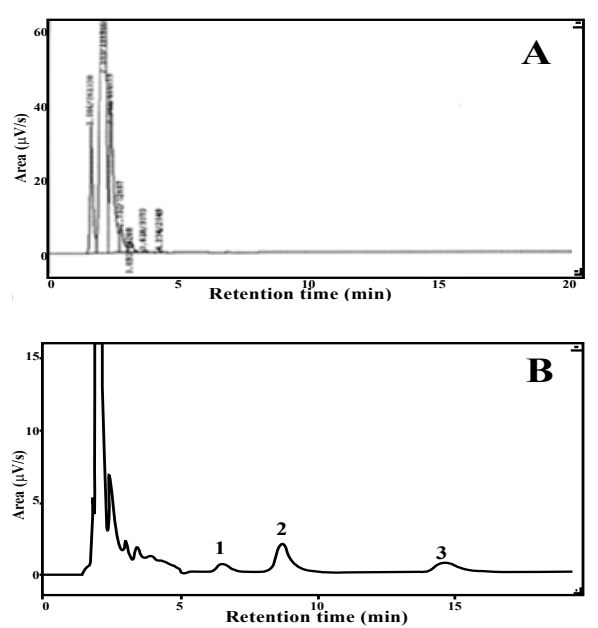

Figure 1: Representative chromatogram of human blank plasma (A) human blank plasma spiked with trimethoprim (1), sulfadimidine (2), and sulfamethoxazole (3) (B). 
Citation: Harmita, Mansur U, Sartika J (2012) Optimation and Validation of Analytical Method of Cotrimoxazole in Tablet and Plasma In vitro by High Performance Liquid Chromatography. J Bioanal Biomed 4: 026-029. doi:10.4172/1948-593X.1000059
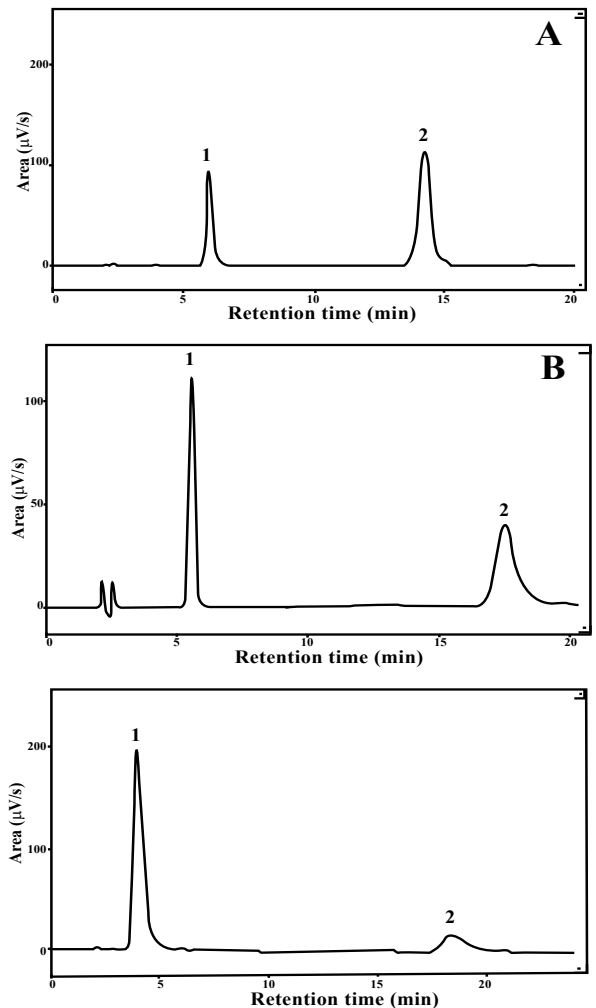

Figure 2: Chromatogram of trimethoprim (1) and sulfamethoxazole (2) in different $\mathrm{pH}$ of mobile phase. The chromatograms representative system in $\mathrm{pH} 5.9(\mathrm{~A}) ; \mathrm{pH} 4.0(\mathrm{~B})$; and $\mathrm{pH} 7.5(\mathrm{C})$. replicate calibration curves on different days was more than 0.996 for trimethoprim and more than 0.995 for sulfamethoxazole. The lower limit of quantification with a coefficient of variation of less than $20 \%$ was $150 \mathrm{ng} / \mathrm{mL}$ for trimethoprim and $750 \mathrm{ng} / \mathrm{mL}$ for sulfamethoxazole.

\section{Precision and accuracy}

The coefficient variation values of both inter- and intraday analysis for 5 days at three concentrations which each concentration is conducted at 5 replicates were less than $7.11 \%$ for trimethoprim and $6.51 \%$ for sulfamethoxazole whereas the $\%$ differentiation were less than $13.85 \%$ for trimethoprim and $13.63 \%$ for sulfamethoxazole. The inter- and intra-day precision and accuracy values of the assay method are presented in Table 1.

\section{Recovery}

The mean extraction recoveries of cotrimoxazole at three concentrations (low, mid, high) respectively were $85.62 \%-102.91 \%$, $95.17-101.27 \%$, and $90.17 \%-92.34 \%$ for trimethoprim whereas for sulfamethoxazole were $80.07 \%$ - 98.59\%, $82.53 \%-94.40 \%$, and $87.78 \%$ - $89.14 \%$.

\section{Stability}

Treated plasma samples were found to be stable at least $24 \mathrm{~h}$ when the samples were kept at room temperature (\%diff $<15 \%)$. The concentrations of cotrimoxazole in plasma which underwent three freeze-thaw cycles or storage at $-20^{\circ} \mathrm{C}$ for 30 days were found to be stable with $\%$ differentiation less than $15 \%$. The stability data of cotrimoxazole stored under various conditions and subjected to freezethaw cycles are shown in Table 2. The primary stock solutions were also found to be stable for 40 days when were kept at $5^{\circ} \mathrm{C}$. The stability

\begin{tabular}{|c|c|c|c|c|c|c|}
\hline \multirow[t]{2}{*}{ Concentration } & \multicolumn{2}{|l|}{ Mean $\pm \mathrm{SD}(\mu \mathrm{g} / \mathrm{mL})$} & \multicolumn{2}{|c|}{ CV (\%) } & \multicolumn{2}{|l|}{$\%$ diff } \\
\hline & TMP & SMX & TMP & SMX & TMP & SMX \\
\hline \multirow[t]{2}{*}{ Low } & $0.4240 \pm 0.0219$ & $2.1572 \pm 0.1002$ & 5.23 & 4.71 & Min $=-0.92 \%$ & Min $=-0.02 \%$ \\
\hline & & & & & $\operatorname{Max}=12.09 \%$ & Max $=13.62 \%$ \\
\hline \multirow[t]{2}{*}{ Mid } & $0.6444 \pm 0.0269$ & $3.3959 \pm 0.1645$ & 4.15 & 4.87 & $\operatorname{Min}=0.10 \%$ & $\operatorname{Min}=0.02 \%$ \\
\hline & & & & & $\operatorname{Max}=-11.74 \%$ & $\operatorname{Max}=13.22 \%$ \\
\hline \multirow[t]{2}{*}{ High } & $0.9884 \pm 0.0358$ & $5.1658 \pm 0.1981$ & 3.65 & 3.90 & $\operatorname{Min}=0.50 \%$ & $\operatorname{Min}=-0.02 \%$ \\
\hline & & & & & $\operatorname{Max}=-14.60 \%$ & $\operatorname{Max}=13.63 \%$ \\
\hline
\end{tabular}

Table 1: Accuracy and precision from the determination of cotrimoxazole in human plasma ( $n=25 /$ concentration).

\begin{tabular}{|c|c|c|c|c|c|}
\hline \multirow{2}{*}{ Concentration } & \multirow[b]{2}{*}{ TMP } & CV (\%) & \multicolumn{3}{|c|}{$\%$ diff } \\
\hline & & SMX & TMP & SMX & \\
\hline \multicolumn{4}{|c|}{ Short term stability for $24 \mathrm{~h}$ in plasma at room temperature } & & \\
\hline Low & 6.32 & 1.45 & $2.06-14.83 \%$ & \multicolumn{2}{|c|}{$0.78-3.36 \%$} \\
\hline High & 1.22 & 1.29 & $-3.57-(-) 1.46 \%$ & \multicolumn{2}{|c|}{$-0.16-2.19 \%$} \\
\hline \multicolumn{6}{|c|}{ Long term storage at $-20^{\circ} \mathrm{C}$ for 30 days } \\
\hline Low & 3.95 & 9.18 & $-14.22-(-) 7.18 \%$ & \multicolumn{2}{|c|}{$-7.17-10.57 \%$} \\
\hline High & 3.20 & 2.70 & $2.04-8.77 \%$ & \multicolumn{2}{|c|}{$-0.07-4.82 \%$} \\
\hline \multicolumn{6}{|c|}{ Three freeze/thaw cycles } \\
\hline Low & 0.64 & 3.31 & $-11.74-(-) 10.60 \%$ & -10.80 & $-(-) 5.51 \%$ \\
\hline High & 0.06 & 0.04 & $-13.92-(-) 3.75 \%$ & -11.56 & $-(-) 4.08 \%$ \\
\hline
\end{tabular}

Table 2: Stability data of cotrimoxazole in human plasma. 
Citation: Harmita, Mansur U, Sartika J (2012) Optimation and Validation of Analytical Method of Cotrimoxazole in Tablet and Plasma In vitro by High Performance Liquid Chromatography. J Bioanal Biomed 4: 026-029. doi:10.4172/1948-593X.1000059

data of cotrimoxazole stored under various conditions and subjected to freeze-thaw cycles are shown in Table 2.

\section{Discussion}

\section{Preparation of plasma samples}

Protein precipitation has the advantages of simplicity and universality, so it was used to prepare the plasma samples [3]. The reason of choosing acetonitrile as the precipitation agent was caused by its ability to precipitate protein, especially when given not less than the volume of blood. It is also usually become the component of mobile phase with the result that the system will be able to accept. Results indicated that direct protein precipitation with acetonitrile was simple and rapid and good separation of the drug and I.S. was achieved using the precipitation method. The centrifugator was used optimally on $12500 \mathrm{rpm}$ for 15 minutes. The aim was to obtain the pure supernatant which was ready to be injected.

\section{Optimization of mobile phase}

The chromatographic conditions were optimized by injecting analytes with mobile phase containing varying percentages of organic phase, flow rates and $\mathrm{pH}$ of mobile phase to achieve good resolution and symmetric peak shapes for trimethoprim, sulfamethoxazole and sulfadimidine, as well as a short retention time. As expected, the retention times increased with decreasing acetonitrile percentage and system flow rates. The chosen mobile phase $\mathrm{pH}$ was $5.9 \pm 0.1$ by giving the most symmetric peak shapes for trimethoprim, sulfamethoxazole, and sulfadimidine.

Triethylamine was added to improve peak shapes. Thus, optimal conditions were a mobile phase consisting of acetonitrile, water, and triethylamine $(20: 80: 0.1, \mathrm{v} / \mathrm{v} / \mathrm{v}) \mathrm{pH} 5.9 \pm 0.1$ arranged by $0.2 \mathrm{~N} \mathrm{NaOH}$ or $1 \%$ acetic acid. Under optimum conditions, the chromatographic run time for each sample was completed within $18 \mathrm{~min}$.

\section{Advantages of the method}

In comparison to previously published HPLC methods for separation and quantitation of cotrimoxazole, the major modifications incorporated into the current method include: simple sample preparation procedures, common and cheap HPLC equipment and mobile phase additives, and a relative short analysis time as well.

Thus the assay is suitable for routine analysis when determining assay on tablet and biological samples to perform bioequivalence studies. A simple, rapid, precise, and accurate HPLC method for determining cotrimoxazole in human plasma has been presented. Although lower sensitivity was obtained in comparison to previously published LC methods with mass spectrometry detection, the resulting LLOQ (150 $\mathrm{ng} / \mathrm{mL}$ for trimethoprim and $750 \mathrm{ng} / \mathrm{mL}$ for sulfamethoxazole) was sufficient for human pharmacokinetic studies.

\section{Conclusion}

An analytical method developed for cotrimoxazole quantification in tablet and plasma samples showed good specificity, sensitivity, linearity, precision, and accuracy over the entire range of clinically significant and therapeutically achievable plasma concentrations, thereby enabling its use in bioequivalence trials.

\section{References}

1. Blood (2009) January 8,2010
2. Departemen Kesehatan Republik Indonesia (1995) Farmakope Indonesia (Ed ke-4) Jakarta.

3. Evans, Gary (Ed.) (2004) A handbook of bioanalysis and drug metabolism USA: CRC Press.

4. Food and Drug Administration (1994) Validation of chromatographic methods Reviewer guidance

5. Food and Drug Administration (2000) Analytical procedures and method validation. Guidance for industry, Februari 2, 2010.

6. Food and Drug Administratio (2001) Bioanalytical method validation. Guidance for industry. November 15, 2009.

7. Food and Drug Administration (2003) Q1A(R2) Stability testing of new drug substances and products. Guidance for industry, November 15, 2009

8. Galichet, Laurent Y (Ed.) (2005) Clarke's analysis of drugs and poisons London: Pharmaceutical Press.

9. Gandjar, Ibnu G, Rohman A (2007) Kimia farmasi analisis. Yogyakarta: Pustaka Pelajar.

10. Gilman AG (2006) The Pharmacological basis of therapeutics (11th ed.) USA Macmillan Publishing.

11. Gunawan, Gan S (Ed.) (2008) Farmakologi dan terapi (Ed. ke-5). Jakarta: Bala Penerbit FK UI.

12. Hadjar, Mohammad MI (1985) Teknik analisis obat dalam cairan biologis dengan GLC dan HPLC. In: Cermin Dunia Kedokteran (No. 37, hlm. 26-31) Jakarta: Pusat Penelitian dan Pengembangan PT. Kalbe Farma.

13. Harmita (2006) Buku ajar analisis fisikokimia. Depok: Departemen Farmasi FMIPA Universitas Indonesia

14. Katzung BG, Masters SB, Trevor AJ (2009) Basic and clinical pharmacology McGraw-Hill San Fransisco.

15. Laizure SC, Holden CL, Stevens RC (1990) lon-paired high-performance liquid chromatographic separation of trimethoprim, sulfamethoxazole and $\mathrm{N}^{4}$-acetylsulfamethoxazole with solid-phase extraction. In: Lunn, George. \& Schmuff, Norman. (1997) HPLC Methods for Pharmaceutical Analysis. USA Wiley Interscience.

16. Mistri HN, Jangid AG, Pudage A, Shah A, Shrivastav PS (2009) Simultaneous determination of sulfamethoxazole and trimethoprim in microgram quantities from low plasma volume by liquid chromatography-tandem mass spectrometry. Microchemical Journal 94: 130-138.

17. Moffat AC (Ed.) (1986) Clarke's isolation and identification of drugs in pharmaceuticals, body fluid, and post mortem material (2nd ed.) London: The Pharmaceutical Press.

18. Moore KHP, Brouwer KLR (1995) High-performance liquid chromatographic evaluation of the effect of heat treatment on trimethoprim and sulfamethoxazole stability in serum. In: Lunn, George \& Schmuff, Norman. (1997) HPLC Methods for Pharmaceutical Analysis. USA: Wiley Interscience.

19. Ronn Anita M, Mutabingwa TK, Angelo KS (1999) A reversed-phase high-performance liquid chromatography method for the determination of cotrimoxazole (trimethoprim/ sulphamethoxazole) in children treated for malaria. Desember 8, 2009.

20. Henner ST (Ed.) (2005) Preparative chromatography of fine chemicals and pharmaceutical agents. Germany: Wiley-VCH.

21. Wu-Pong SL, Yu S, Andrew BC (2004) Applied biopharmaceutics and pharmacokinetics (5th ed.) USA: Appeton \& Lange.

22. James S, Boylan James C (Ed.) (1988) Encyclopedia of pharmaceutica technology. Vol.1. New York, USA.

23. Synder Lloyd R, Kirkland, Joseph J, Glajch (1997) Practical HPLC method development (2nd ed.). USA: John Wiley \& Sons.

24. The United State Pharmacopeial Convention (2006) United states of pharmacopeia 30 - national formulary 25 , USA.

25. Vogel, Arthur Israel (1989) Textbook of quantitative chemical analysis. Inggris: Longman Scientific \& Technical. 